\title{
A prágai Ost und West magyar vonatkozású közleményei 1837-1848
}

A Prágában megjelenő német nyelvü Ost und West az 1848 előtti polgári átalakulás korának Európa-szerte sokat hivatkozott, általánosan olvasott lapja volt. Szisztematikus feldolgozása magyar szempontból eddig még nem történt meg. Az Ost und West. Blätter für Kunst, Literatur und geselliges Leben címü folyóirat 1837 és 1848 között jelent meg. Szerkesztőjének, Rudolf Glasernek célkitüzése a Kelet és Nyugat közti közvetítés volt, lapja sok cseh, morva, orosz és lengyel irodalommal kapcsolatos írást közölt, de más országok kultúrájával is foglalkozott. Szerepeltek benne novellák, drámák, versek, útleírások, országismereti, zenei, színházi és más mủvészeteket tárgyaló közlemények. Ezek a kor mủvelt polgárságának érdeklődését voltak hivatottak kiszolgálni. A cseh népköltészet kiemelt helyet foglalt el a témák között; emellett 1838-tól 1840 végéig rendszeresen közölték a cseh irodalom legújabb termékeinek bibliográfiáját.

A folyóirat a reformkorban több helyütt előforduló német nyelvü irodalmi lap típusába tartozott. Reinhard Wittmann így jellemzi a korszak sajtóját: „A Vormärz sajtójára a szépirodalmi lapok relatív magas száma volt jellemző, amelyek gyakorta pótlékszerepet töltöttek be, az elnyomott politikai sajtó helyett az esztétikai-szórakoztató szerepen túl a liberális polgárság kommunikációs fórumaiként szolgáltak.[...] Menzel Literaturblattjában, Saphir Humoristjában, Herloßsohn Kometjában, vagy akár a pengős magazinokban jelen volt a politika - már amennyire a cenzúra engedte." ${ }^{1}$ Ebbe a típusba tartozott a Ludwig August Frankl által a párizsi Revue des Deux Mondes mintájára alakított Sonntagsblätter für heimatliche Interessen (1842-1848) címü hetilap, ${ }^{2}$ valamint a pesti Spiegel is (1829-1852), amely azonban túlélte 1848-at. Ezek a kelet-európai német nyelvü lapok, ha nem is személyes kapcsolatokon keresztül, de összeköttetésben álltak egymással, figyelték egymást, átvettek híreket egymástól, több munkatársuk dolgozott egyidejűleg több lap számára. A pest-budai és a pozsonyi német nyelvü lapok gyakran támaszkodtak az Ost und West anyagára, átvettek szláv népdalo-

${ }^{1}$ Wittmann, Reinhard, Buchmarkt und Lektüre im 18. und 19. Jahrhundert, Beiträge zum literarischen Leben 1750-1880, Tübingen, Max Niemeyer, 1982, 149.

2 ZENKER, Ernst Victor, Geschichte der Journalistik in Österreich, Wien, Hof- und Staatsdruck, $1900,26$. 
kat, népmondákat belőle, és tudósítottak a szlovák, cseh, morva, szlovén, szerb, lengyel és orosz irodalmi-kulturális törekvésekröl. ${ }^{3}$

Az 1848-ban 150000 lakossal rendelkező Prágában 37 szórakozató lap létezett, ebből 29 német nyelven. ${ }^{4}$ Az Ost und Westet 1837. június végén mint új irodalmi jelenséget elöre beharangozták egy röplapon. ${ }^{5}$ 1837. július 1 -jétől aztán már rendszeresen hetente háromszor jelent meg a periodikum. ${ }^{6}$

Az új orgánum célja a szláv Kelet és Németország közti irodalmi kapcsolatok fejlesztése volt. Erre a szerepre Csehország - részben szláv, részben német lakosságával - az európai Kelet és a Nyugat határaként kiválóan alkalmas. ${ }^{7}$ A röplap tudósítása szerint a tervezett lap tematikájába novellák, mondák, mesék, versek, továbbá a filozófia, pszichológia, esztétika, a természettudományok, a történettudomány tárgyköréből vett tanulmányok, híres irodalmárok és müvészek életrajzainak közlése tartozott. Megjelentetni kívántak ezenkívül országismereti írásokat, útleírásokat, fordításokat, különös tekintettel a szláv népköltészetre. Egyes számokhoz kottákat és dalszövegeket is mellékeltek. Európa sok fővárosából tudósítottak a müvészet, az irodalom és az ipar újdonságairól. Meg kell jegyezni, hogy a szláv nyelvü országok mellett Magyarországra is fordítottak figyelmet. A prágai színházi életről rendszeresen adtak hírt. A lap kiadójaként Jakob Sambs „egyszerü német postai alkalmazott" nevét tüntették fel, aki egész spórolt pénzét az Ost und West sajtóvállalkozásnak szentelte, ${ }^{8}$ szerkesztője pedig Rudolf Glaser volt. ${ }^{9}$

A szerkesztö, Rudolf Glaser (Prága, 1801 - Prága, 1868) jogi és filozófiai stúdiumok után a prágai Egyetemi Könyvtár alkalmazottja volt, emellett verseket írt. A forradalom leverése után, a politikai elnyomás évei alatt Glaser lemondott mindenfajta publikálásról, teljesen visszavonultan ért a prágai Klementinum skriptoraként, illetve passzióból keleti nyelvek tanulmányozásának szentelte magát. Lefordította perzsából a Sakuntalá címú eposzt, de ez nem jelent meg nyomtatásban. Glaser 1854-től még a prágai Fürstenbergek könyvtárát vezette, később a „Csehországi németek szövetségé"-nek a könyvtárát is. ${ }^{10}$ Glaser jelentőségét a cseh kultúrtörténet számára Karl Viktor Hansgirg (Pilsen/Plzeň, 1823 - St. Joachimsthal/

${ }^{3}$ FrIED, István, Die Kultur des Bürgertums deutscher Muttersprache im Pest-Ofen zur Zeit des Vormärz = Methodologische und literarhistorische Studien zur deutschen Literatur Ostmittel- und Südosteuropas, Hrsg. v. Anton Schwob, u. Mitarbeit v. Carla Carnevale u. Fridrun Rinner, München, Verlag Südostdeutsches Kulturwerk, 1994, 94.

${ }^{4}$ Hofman, Alois, Die Prager Zeitschrift ,, Ost und West”, Ein Beitrag zur Geschichte der deutschslawischen Verständigung im Vormärz, Berlin, Akademie Verlag, 1957, 15-16.

${ }^{5}$ Hofman 1957, i. m. 27.

${ }^{6}$ Lásd ehhez: Časopisectví v Čechách 1650-1847: přispěvek $k$ soupisu periodického tisku, zejména novin a časopisů, Ed. Laiske, Miroslav, Praha, Státní knihovna ČSR - Národní knihovna, 1959 [i. e. 1960]. 179 s., [12] s. obr. př́l. Bibliografický katalog ČSR - České knihy 1959; zvláštní seš. 6, prosinec 1959, 98. Ezt az adatot Pavlina Kafkovának köszönöm meg.

\footnotetext{
7 Hofman 1957, i. m. 27.

${ }^{8}$ Hofman 1957, i. m. 33.

9 Hofman 1957, i. m. 28.

${ }^{10}$ Hofman 1957, i. m. 38.
} 
Jáchymov, 1877) költő, aki egyébként szintén sokat publikált az Ost und Westben, a következőképpen foglalta össze nekrológjában: „Példája arra tanítja meg a történészt, hogy Csehországban a nemzetek áldatlan harcát nem a németek kezdték. A németek békésen viszonyultak a csehek nemzeti törekvéseihez egy olyan korban, amikor a többség az ö oldalukon állt, és könnyü lett volna a cseh nemzeti törekvéseket már csírájukban elfojtani." 11

A lap Európa-szerte ismert és olvasott volt. ${ }^{12}$ Ennek, valamint irodalmi szövegek átvételének és német nyelvủ fordítások cirkulálásának Európában egyik bizonyítéka Mihail Lermontov Álom (Son - Der Traum) című verse. A fordítást az Ost und West közölte 1845-ben, fordítója [Johann] August Mettlerkamp (Hamburg, 1810 - ?, 1859) volt. ${ }^{13}$ Moritz Gottlieb Saphir bécsi Humoristja is közölte a versfordítást, de a fordító neve nélkül 1846. július 16-án. ${ }^{14}$ Saphir ezek szerint vagy az Ost und Westben olvashatta a fordítást, vagy Mettlerkamp szintén 1846ban Braunschweigben megjelent Liederschwalben címú verses kötetében, amely szintén tartalmazta a fordítást. ${ }^{15}$ Mettlerkamp 1840-ben Harkovból, ahol 1835 óta lektorként tevékenykedett az egyetemen, Hamburgba ment szabadságra, és ott megismerkedett Gutzkowval, Hebbellel, Dingelstedttel és a csehországi születésű Uffo Hornnal. Mettlerkamp lefordította még Puskin Mozart és Salieri címü kis drámáját is. ${ }^{16}$ Oroszországba való visszatérése után Lermontov Korunk höse címü regényének fordításán dolgozott, amiből 1846-ban az Ost und West részleteket is közölt. ${ }^{17}$

Az Ost und West szépirodalommal kapcsolatos írásait osztrák, német, orosz és a Balkán országokból származó szerzők küldték be. Állandó levelezői mellett olyan munkatársai voltak, mint Ferdinand Freiligrath, Ludwig August Frankl, Friedrich de la Motte Fouqué, Joseph Mendelssohn, Betty Paoli, Friedrich Rückert, Moritz Gottlieb Saphir, Adolf von Tschabuschnigg, Heinrich Laube, Johann Gabriel Seidl, Karl Beck, Heinrich Ritter von Levitschnigg, Franz Freiherr von Dingelstedt, Karl Gutzkow, Heinrich Wilhelm August Stieglitz, Eduard Gervais, Karl Immermann, Karl Herloßsohn és Johann Nepomuk Vogl. A cseh-morva szerzők

11 Hansgirg, K[arl] V[iktor], Rudolf Glaser (Nekrolog) = Mitteilungen des Vereins für Geschichte der Deutschen in Böhmen, Jg. 8 1870, 87. Ezt az adatot V. Ecsedy Juditnak köszönöm meg.

12 Hofman 1957, i. m. 55.

13 Der Traum. Aus dem Russischen des Lermontow, August Mettlerkamp = Ost und West, Nr. 75, 19. September 1845, 297.

14 Lásd ehhez: Rózsa, Maria, Der Humorist von Moritz Gottlieb Saphir, Mit besonderer Berücksichtigung der Aufnahme von ungarischen Themen 1837-1848 = Uö, Wiener und Pester Blätter des Vormärz und ihre Rolle an der Kulturvermittlung, Kontakte, Parallelen, Literaturvermittlung, Redakteure und Mitarbeiter, Herne, Gabriele Schäfer Verlag, 2013, 67-68 (= Studien zur Literaturwissenschaft, 6).

15 ReISSNER, Eberhard, Deutschland und die russische Literatur 1800-1848, Berlin, Akademie Verlag, 1970, 204-205; S. 362. Ezért az adatért köszönetemet fejezem ki Anna Ananievának.

16 Reissner 1970, i. m. 204-205.

17 Sivers, Jegór von, Deutsche Dichter in Russland, Studien zur Literaturgeschichte, Berlin, Verlag von E. H. Schroeder, 1855, 419-420. 
között említésre érdemesek Moritz Hartmann, Sigmund Kolisch, Isidor Heller, Siegfried Kapper, Adolf Neustadt, Uffo Horn, Karl Viktor Hansgirg, Adolf Wiesner és Ludwig Ritter von Rittersberg.

A Johann Sprunynál, majd 1839. december 11-étől Karl Geržabeknél nyomtatott negyedrét alakú $(23 \times 30 \mathrm{~cm})$ lap minden száma $4-5$, folyamatosan számozott oldalból állt.

Willibald Alexis (tkp. Georg Wilhelm Heinrich Häring (Breslau/Wrocław, Pl., 1798 - Arnstadt, 1871) ismert német író, a német realista regény megteremtője, előszónak egy episztolát küldött a lap szerkesztőjének. Ebben az episztolában kifejti szkeptikus véleményét a szépirodalmi lapokról, amelyeknek tipikus képviselői a Zeitung für die elegante Welt, Der Fremüthige für Deutschland vagy a Morgenblatt für gebildete Stände voltak. Glaser beharangozó írása, illetve a lappal kapcsolatos célkitüzései felkeltették az érdeklődését, az is megnyerte a tetszését, hogy Glaser lapjával a közvetítő szerepét, a szláv irodalom népszerüsítését vállalja fel. Alexis ezt teljesen újnak, még soha nem létezettnek találta. A szláv irodalom ugyanis a Nyugaton alig volt ismert, Puskinon, Besztuzsev-Marlinszkijon, a lengyel Adam Mickiewiczen kívül csak a prágai Karl Egon Ebert (1801-1882), neve volt köztudott, ő az Ost und Westben is rendszeresen publikált.

A lap magyar tudósítói közül kiemelkedik Rumy Károly György (Igló/Spišská Nová Ves, Sk. 1780 - Esztergom, 1847). 1838 és 1841 között Esztergomból küldött írásait a következő módokon írta alá: -u-, m, Dragutin és Karl. Az iglói születésü, cipszer Rumy csak a debreceni református kollégium diákjaként tanult meg magyarul. Ezután teológiát és természettudományokat hallgatott különböző német egyetemeken (Göttingában és Wolfenbüttelben). Később több felvidéki líceumban tanított, majd a keszthelyi Georgicon oktatója lett. 1824-től Bécsben élt, 1828-tól haláláig Esztergomban. A közgazdász, publicista, történész, fordító és népdalgyüjtő Rumy tehát polihisztor volt. A felvilágosodás korának hungarus patriotizmusát képviselte, amely azonban a 40-es években már nem volt összeegyeztethető a haladó értelmiség nézeteivel, és emiatt Rumyt több támadás is érte. ${ }^{18}$ Rumy írásaiban mindig síkra szállt azért, hogy mindenki maga dönthesse el, melyik nyelvet beszéli otthonában, az iskolában vagy a templomban. ${ }^{19}$ Sokirányú érdeklődése, nagy családja miatti állandó anyagi természetü gondjai, valamint nyughatatlan vándorélete nem tették lehetővé számára az elmélyült kutató munkát. Így a tervezett nagy müvek megírására soha nem került sor, de a német nyelvủ lapoknak Közép-Európában állandó levelezője volt. Írásaiban folyamatosan népszerüsítette a magyar kultúrát, és gyakran helyesbítette a Magyarországgal kapcsolatos téves nézeteket. Életrajzírója csak a bécsi Wandererben 1824 és 1835 között 1470 írását számolta össze. ${ }^{20}$ Témái az időjárástól, gazdasági kérdéseken keresztül egészen különböző betegségekig terjedtek. Elkötelezett szószólója volt

18 FrIED, István, Rumy Károly György, a kultúraközvetítő 1828-1847 [Karl Georg Rumy, der Kulturvermittler 1828-1847] = Filológiai Közlöny, 9(1963), Nr. 1-2, 204.

19 Fried 1963, i. m. 208.

${ }^{20}$ KöRÖsy László, Rumy élete [Rumys Leben], Budapest-Esztergom, Aigner-Buzárovtis, 1880, 94. 
a magyarországi szlovákoknak, mindig megemlítette, ha azt látta, hogy a magyar nemesség egyes tagjai elnyomják a szlovák embereket. Sok bécsi és pesti lapnak küldte tudósításait, a Sonntagsblätter, a Humorist, a Pesther Tageblatt és az Ungar állandó szerzője volt.

Az Ost und Westben első alkalommal Crna Gora-i (Montenegro) és belgrádi szerb nyomdákról írt, és ezzel a délszláv nemzetiségek könyvkultúráját népszerüsítette. $^{21}$

Rumy könyvismertetést közölt a Szerb népdalok és hősregék. Az eredetiből fordítá Székács József, kiadá Kunoss Endre (Pest, Trattner-Károlyi, 1836) kötetről. Rumy a fordítást jól sikerültnek tartja, és leszögezi, hogy a szerbek olyan gazdag népdalkincssel rendelkeznek, amivel egyetlen európai nép sem dicsekedhet. Megemlíti Vuk Stefanović Karadžić nevét is, végül kis fordításmintát közöl magyarul és németül. ${ }^{22}$

Rumy egyik írásában filológiai bizonyítékokat sorolt fel sok magyar szó szláv vagy német eredetével kapcsolatban. ${ }^{23}$ Egyik első közleményében Rumy a Hasznos Mulatságok cikkére reagál, és kifejti álláspontját az ,,afterpatriotizmussal” kapcsolatban, vagyis hogy milyen káros a magyar nyelv rákényszerítése a más - föleg szláv nyelvü - népekre. ${ }^{24}$

Kulifai Zsigmond (1796-1868) református lelkésznek a Tudományos Gyüjteményben (1839, 15. sz.) megjelent írására válaszolva Rumy kitér Kulifai azon megállapításaira, hogy a magyarok fó tulajdonságai, illetve elfoglaltságai a bátorság, a gazdálkodás, vendégszeretet. Azonban Kulifai semmit nem ír a magyarok „sötét” oldalairól, véli Rumy. Szerinte ezek a lustálkodás, más népek kigúnyolása, a tudományok lanyha müvelése, illetve azok lebecsülése, a régről maradt felületességhez való ragaszkodás, mások haladásának irigylése, gőgősség, a hírnév hajszolása és minden idegen gyülölete. ${ }^{25}$

Rumy Nagy Elek (1820-1875) ügyvédnek a Hasznos Mulatságokban (1837, 31. sz.) Nemzetek' charactere címen megjelent írására reflektál Hartes und ungerechtes Urtheil eines Magyaren über die Slowaken Ungarns címen az Ost und West vitarovatában. Nagy azt írja, hogy a szlovákok nem nevelik gyermekeiket, mivel maguk is tudatlanok és szegények, ezért gyermekeik vadon nőnek fel. Ezzel szemben Rumy szerint a módos szlovák gyermekeit ugyanolyan jó nevelésben részesíti, mint a jómódú német vagy magyar Magyarországon. Nagy ezen

${ }^{21}$ Dr. Rumy, Die serbischen Buchdruckereien zu Czettin in der Czerna Gora (Montenegro) und zu Belgrad in Serbien = Ost und West, Nr. 59, 25. Juni 1838, S. 244.

22 Dr. Rumy, Magyarische Uebersetzung der serbischen Volkslieder $=$ Ost und West, Nr. 77, 26. September 1838, S. 318; Nr. 78, 29. September 1838, S. 321.

23 Dr. RumY, Aufrichtiges Geständnis eines magyarischen Gelehrten über den fremden Ursprung vieler magyarischen Wörter, und patriotischer Wunsch = Ost und West, Nr. 15, 21. Februar 1838, 64 .

${ }^{24}$ Ry, Unbefangenes Urtheil eines Magyaren über die Verachtung fremder Sprachen, $=O U W$, Nr. 42, 26. Mai 1838, 174.

${ }^{25}-\mathrm{u}-$, Beitrag zur Schilderung des Nationalcharakters der Magyaren, $=$ OUW, Nr. 52, 30. Juni 1838, 216. 
kívül azt az elítélő általánosítást teszi, hogy a szlovákok irigyek és könnyen felbosszanthatóak, emellett büszkék és vérre menően ingerlékenyek. Rumy ezzel szemben úgy véli, hogy mindez „rossz és igazságtalan jellemrajz”, mert „Magyarországon sok katolikus és evangélikus szlovák töltött be és tölt be profeszszori állást, valamint sokan adtak és adnak ki nagy értékủ tudományos múveket." A továbbiakban felsorol egy sor ilyen tudóst. Az, hogy a szlovákok egyáltalán irigyek lennének, puszta rágalom. Úgy véli, a magyar is ugyanolyan könnyen feldühíthető, mint a szlovák, a magyar azonban még büszke is, de más népek, például a spanyolok is büszkék. ${ }^{26}$

$\mathrm{Az}$ - m - aláírású levelező (valószínüleg Rumy) a Századunkban megjelent írással kapcsolatban foglal állást a müvelt világban terjedő új helyesírási szokás, az egyszerüségre törekvés kapcsán, és kitér egyes magyar szavak helyesírására. Rumy ehhez kapcsolja érvelését a német mint a tudományok nyelvének megőrzése mellett. ${ }^{27}$

Az Urteil eines unbefangenen magyarischen Literators über die deutsche Sprache, Journalistik und Literatur in Ungarn címü írásában Rumy Kapuváry Ferdinánd (?-?) rosszalló véleményéhez csatlakozik a pesti német és magyar színházzal kapcsolatban. Ekkorra ugyanis a Magyar Nemzeti Színház már sokkal népszerübb volt, mint a Pesti Német Színház. Rumy a Pesther Tageblatt védelmére kel, és kifejti álláspontját, mi szerint egy német nyelvű lap kiadása semmiképpen nem hazafiatlanság, vagy hazaárulás. Ismételten aláhúzza a német nyelv mint a kultúra hajtóerejének és terjesztőjének fontosságát. ${ }^{28}$ Rumy több magyarországi német nyelvü orgánumban, így például a Pesther Tageblattban is síkra szállt a német nyelv kultúraközvetítő szerepe mellett, és ezért sok támadás is érte, hazafiatlansággal vádolták. ${ }^{29}$

Rumy egy Esztergomból küldött levelében Karel Sabina (1813-1877) cseh írónak a Pesther Tageblatttal folytatott vitájában a cseh író oldalán foglal állást. Sabina azt állította, hogy a lap a cseh nyelvnek és irodalomnak közeli véget jósol. Írásának második részében Rumy egy Bécsben élő cseh ember panaszára reflektál, aki arra panaszkodott, hogy a bécsi kávéházakban nincsenek cseh lapok kitéve. Rumy erre válaszova leszögezi, hogy ezzel szemben a pesti kávéházakban több szláv nyelvü újság olvasható. Véleménye szerint erről a helyzetről a csehek tehetnek, mert nekik maguknak kellene valamit tenniük azért, hogy a kávéházakban az érdeklődők megtalálhassák a számukra fontos cseh lapokat. Rumy ezen

${ }^{26}$ Dr. Rumy, Hartes und ungerechtes Urtheil eines Magyaren über die Slowaken in Ungarn= OUW, Nr. 83, 16. Oktober 1839, 358-359.

27 - m -, Verschiedenheit des Studiums der Philologie unter den Magyaren und Ausländern, = OUW, Nr. 95, 27. November 1839, 415.

${ }^{28}$ Dr. Rumy, Urtheil eines ubefangenen magyarischen Literators über die deutsche Sprache, Journalistik und Literatur in Ungarn = OUW, Nr. 96, 30. November 1839, 422-423.

${ }^{29}$ Lásd ehhez: Rózsa, Maria, Die Kulturvermittlerrolle des Pesther Tageblattes. 1839-1845 = Wiener und Pester Blätter des Vormärz und ihre Rolle an der Kulturvermittlung, uo., 102. 
kívül tanúbizonyságát adja annak, hogy a Monarchia délszláv sajtójával kapcsolatos széles körü ismeretekkel rendelkezik. ${ }^{30}$

Egyik tudósításában Rumy a pesti Spiegel egyik írásával kel vitára Theodor Körner német költő és író Zriny című drámája hősének szláv származásával kapcsolatban, és különböző forrásokat vonultat fel, amelyek bizonyítják Zrínyi Miklós horvát származását, ezen kívül bemutatja a Budán kiadott szlovén Zora almanachot. ${ }^{31}$

A Controlle des Ultramagyarismus polémiára késztető címet viselö írásában Rumy a Pozsony és környékén élő szlovákok elmagyarosítása ellen emel szót, és a szlovákok történelmi jogára hivatkozik, melynek értelmében ők ott őshonosak. Az a követelés, hogy Magyarországon egy közös nyelv, a magyar, legyen, méltánytalan, és ennek természetesen politikai okai vannak. „Az igazi hazafiság összeköthetö a kozmopolitizmussal" - véli. ${ }^{32}$

A multikulturális, többnyelvü közegből származó Rumy előítéletmentesebben tudott a különböző nemzetek együttélési problémáival kapcsolatban állást foglalni. A szlovákok és magyarok szociális körülményeiröl alkotott megállapításai saját megfigyelésen alapultak, és szinte korai szociológiai felmérésként olvashatóak.

Rumy Magyarországról küldte tudósítását a Bécsben élő Csaplovics Jánosnak Bajzával a Századokban folytatott vitájával kapcsolatban, melyben a pesti és budai német színházak magyarosítási törekvéseiről volt szó. Csaplovics irónikusan írta Bajza írására válaszolva, hogy a magyar Nemzeti Színház felvirágzásához nincs szükség másra, csak vízre, vagyis a színház épületét a Dunához közelebb kellene helyezni, valamint azt állította, hogy a pest-budai németeket ostorral kell a Nemzeti Színházba terelni. Ekkorra a pesti Német Színház már sokat vesztett népszerüségéből. Rumy megvédte a két város 120000-es lakosságát, amelyben sok a német nyelvü, akiknek joga van német nyelvủ színházra. ${ }^{33}$

Egy rövid írás a „tót” szó eredetével és a „tót nem ember” közmondással foglalkozik. Megemlíti Ivan Kukuljević drámaírót, aki a magyarok őseinél a „tót” szó jelentését „a „bölcsesség atyja, félisten” értelemben definiálja, ezzel is alátámasztva a szó pozitív jelentését. ${ }^{34}$

Szintén Rumy tudósított a Magyar Tudományos Akadémia 1845. december 29-ei üléséről, amelyen Frankenburg Adolf (1811-1886) tartotta székfoglaló beszédét. Ezt követően az Akadémia pályadíjainak kihirdetéséről számolt be, melyeket természettudósok kaptak, majd a Tudomány és Irodalom címmel kiadni

${ }^{30}$ Dr. Karl Rumy, Correspondenz aus Gran $=$ OUW, Nr. 96, 30. November 1839, 418-419; Nr. 97, 4. Dezember 1893, 427-428.

${ }^{31}$ Dragutin $=O U W$, Nr. 3, 8. Januar 1840, 11.

32 Ld. Hofman, uo., 80-81; KarL, Controlle des Ultra-Magyarismus $=O U W$, Nr. 7, 22. Januar 1840, 27.

${ }^{33} \mathrm{a}-\mathrm{O}$, Ansicht des Herren Johann v. Csaplovics in Wien in Betreff der Magyarisierung der Pesther und Ofner Deutschen Theater durch das magyarische Nationaltheater in Pesth $=O U W$, Nr. 31, 16. April 1841, 128.

${ }^{34}$ Ld. Hofman, uo., S. 81; Thót nem ember $=O U W$, Nr. 79, 1. Oktober 1841, 320. 
tervezett folyóiratról, amely azonban nem valósult meg. Rumy megemlítette Kovacsóczy Mihály (1801-1846) ügyvéd és szerkesztő Lipcsében név nélkül kiadott Magyarkák (Teubner, 1845) címü röpiratát, amelyben a szerző több magyar író portréját mutatja be, amelyeket azonban Rumy nem találja jól sikerültnek és idézi a Pesti Hírlap idevágó kritikáját. Végezetül kitér Karacs Teréz (1808-1892) írónőre, aki a jobbak és közkedveltebbek közé tartozik, valamint megemlíti Peter Jovanović újvidéki szerb professzor Bačka Vila címü almanachját. ${ }^{35}$

A „Literatur”rovatban jelent meg rövid híradás Jósika Miklós Zrínyi a költő című regényének Steinacker Gusztáv által készített és 1844-ben Heckenastnál megjelent német fordításáról. ${ }^{36}$ A recenzens szándéka szerint nem foglalkozott a mủvel részletekbe menően, csak az anyag gazdagságát említette meg, kitért viszont a történelmi háttér bemutatására és a női jellemekre.

Bár a magyar irodalom népszerüsítése nem tartozott az Ost und West által preferált témák közé, mégis három alkalommal közölt a lap magyar szépirodalmi műveket. 1846-ban jelent meg Zerffi Gusztáv fordításában Hiador (Jámbor Pál) Emléklapok egy förangú hölgyhöz címü versciklusa a Honderü alapján. ${ }^{37} \mathrm{Az}$ objektivitás kedvéért: Jámbor a biedermeier almanach-líra középszerú képviselöje volt, akinek költészete a kortársak körében vagy visszhangtalan maradt, vagy megsemmisítő kritikában részesült. A kalandos életủ és ellentmondásos személyiségü Zerffi (szül. Hirsch, Buda, 1820 - London, 1892) fordításai számos német nyelvü lapban láttak napvilágot. A reformkorban a Spiegel munkatársa volt, majd 1848. október 1-jétől a formájában és tartalmában átalakított Ungar társszerkesztője. 1848 januárjától 1848. július 19-éig a Morgenröthe szerkesztője. A figyelmet Petőfit támadó írásaival hívta fel magára, majd 1848-ban a forradalom lelkes híve lett, és lefordította németre Petőfi Nemzeti dalát (Nationalhymne der Magyaren). A szabadságharc leverése után emigrált, és Londonban élt kettős életet, egyfelől mint elismert tudós, másfelől mint a bécsi udvar ügynöke. ${ }^{38}$

A Lerma gróf feleségének, Laurának próbák kiállása útján való lelki megnemesítéséről szóló Madridban játszódó romantikus novellát Julie Großmann fordította szabadon. Az S. M. monogrammal jelölt magyar szerzőt nem sikerült beazonosítani. Hogy a Sziléziában született Julie Großman (szül. von Menzel, Freistadt/Fryštát, Cs., 1790 - Drezda, 1860) tudott-e egyáltalán magyarul, vagy nyersfordítást használt, esetleg valaki segítségére volt a fordításban, ma már nehéz lenne kideríteni. ${ }^{39}$

${ }^{35} \mathrm{y}$, Aus Ungarn, $=$ OUW, Nr. 13, 31. Januar 1846, 51.

${ }^{36}$ E, Zrinyi der Dichter, $=$ OUW, Nr. 8, 28. Januar 1845, 31-32.

37 „Erinnerungsblätter. An eine hochgeborne Dame”, Nach ÍHIADOR von G. I. ZERFFI = OUW, Nr. 85, 18. Juni 1846, 337; Nr. 88, 25. Juli 1846, 349; Nr. 90, 30. Juli 1846, 357; Nr. 99, 20 August $1846,393$.

${ }^{38}$ Zerffiről lásd: Frank Tibor, Egy emigráns alakváltásai: Zerffi Gusztáv pályaképe, 18201892, Bp., Akadémiai Kiadó 1985, 330, [28] t.

39 Laura, Novelle frei nach dem Ungarischen des S. M. von J[ulie] GrossmanN $=O U W$, Nr. 27, 4. März 1847, 105-107; Nr. 28, 6. März 1847, 109-110; Nr. 29, 9. März 1847, 113-114; Nr. 30, 
Több magyar kulturtörténeti írás származik a lapban Antonín Fähnrich (Št'áhlav u Plzni 1802 - Jičín, 1852) professzortól. Fähnrich gimnáziumi tanár, a filozófia doktora volt, több lapban publikált, valamint cseh és német nyelvủ szótárakat adott ki. Az Ost und Westben népszerüsítő cikket közölt a zalavári szlovénok templomáról, melyet 850-ben szenteltek fel. ${ }^{40}$ Szintén ő írt Szliács Nyitra megyei fürdőhelyről. ${ }^{41}$

A gróf Majláth János (1786-1855) történész és költő által szerkesztett, szép kiállítású Iris almanachot az egész Monarchiában ismerték és dicsérték. 1847es évfolyamát Karl Viktor Hansgirg recenzeálta az Ost und Westben. „Ahogy Mailáth almanachja tartalmát és külső eleganciáját tekintve általában kiemelkedik Dél-Németország almanachjaitól és évkönyveitől, úgy az ez évi is" - írta. A recenzens a kötet szerzői közül kiemeli Heinrich Ritter von Levitschnigget, Hermann Kleint, Adalbert Stiftert és Julie Großmannt. ${ }^{42}$

Pusztán tematikailag köthető Magyarországhoz egy ismeretlen költő - a szerkesztői közlemény szerint - Bukarestből beküldött tájleíró verse. ${ }^{43}$

A lap 1847-ben három részletben közölte Kisfaludy Károly Mit csinál a gólya? címü elbeszélését. ${ }^{44}$ A müfordítóról, Adam Süßről sajnos nem sikerült semmilyen életrajzi adatot találnom. Az 1824-ben keletkezett szatirikus-realista novella andekdotaszerủen tematizálja a magyar falu feudális elmaradottságát. Az egyes szám első személyben elmondott történet elbeszélője egy falu templomának tornyán halott gólyát lát függeni. Kérdésére, hogy hogyan került oda a gólya, a falusi bíró és a falu jegyzője, aki egyébként korábban teljesen értelmetlenül lelőtte a gólyát, meséli el a történetet és a falu cigányának a madár leszedésére tett sikertelen kísérletét, miközben az lábát törte. Következö látogatásakor a faluban már nincs ott a gólya a toronyban, mert - mint megtudja - egy forgószél lefújta onnan. A történet a falu lakosainak teljes tehetetlenségét példázza, akik egyébként mind tipikus figurák, akik fizetni nem hajlandóak azért, hogy valaki szakszerüen levegye onnan a gólyatetemet, de - mivel ők maguk nem képesek megoldani a problémát - az időre bízzák annak megoldását, hiszen az idő majd csak elrendezi valahogy a dolgot.

Helyi érdekességekről (a pesti színházakban bemutatott darabok rövid színi kritikái, koncertek, újonnan elkészült épületek) tudósított Julian Chownitz (Ér-

11. März 1847, 117-118; Nr. 31, 13. März 1847, 121-122; Nr. 32, 16. März 1847, 125-126; Nr. 33, 18. März 1847, 129-130; Nr. 34, 20. März 1847, 133-134; Nr. 35, 23. März 1847, 137-138.

${ }^{40}$ FäHnRICH, Ant., Die geschichtlich erste slawisch christliche Kirche zu Szalavár in Ungarn= OUW, Nr. 67, 5. Juni 1847, 265-267.

${ }^{41}$ FäHNRICH, prof. A., Das elektrische Bad zu Sljać in slaw. Ungarn im Neusohler Comitat = OUW, Nr. 67, 5. Juni 1847, 326.

${ }^{42}$ HansGiRg, Karl Viktor, Iris, Deutscher Almanach für das Jahr 1847, Pest Gustav Heckenast $=$ OUW, Nr. 79, 3. Juli 1847, 315; Nr. 80, 6. Juli 1847, 319.

${ }^{43}$ St. - b... r, Auf der Ungarnpuszta $=$ OUW, Nr. 82, 10. Juli 1847, 325.

${ }^{44}$ Was macht der Storch? Eine Dorfgeschichte. Frei nach dem Ungarischen des Karl Kisfaludy von Adam Süss $=O U W$, Nr. 92, 3. August 1847, 365-366; Nr. 93, 5. August 1847, 369-370; Nr. 94, 7. August 1847, 374. 
sekújvár/Nové Zámky Sk., 1814 - Döbling, 1888) „Tags-Noveletten aus Pesth” címü rovatában. ${ }^{45}$ Cownitz/Chowanetz báró egy német tiszt fia volt, az olmützi kadettiskolában tanult, egy darabig tisztként szolgált, majd 1836-tól Németországban több helyen is újságíróskodott. Németországban kiadott röplapjaiban kritizálta a Metternich-rendszert, aztán Grazban vasúti alkalmazott lett. 1839-ben Pesten találjuk, ahol megjelentette a Pesther Charivari címü napilapot, amelyből mindössze egyetlen szám, a június 20 -ai maradt fenn, $\mathrm{s}$ amelyet rögtön betiltottak. Chownitz 1848-ban csatlakozott a magyar forradalomhoz, ismét újságkiadásba kezdett, 1848. április 10-étől 1849. július 8-áig kiadta a radikális Opposition címü bulvárlapot, melynek sikerét a helyszíni tudósítások frissessége alapozta meg. Mikor Jelačić csapatai közeledtek, 1849. szeptember 25-én Bécsbe szökött, majd ott is Opposition címen adott ki lapot. A bécsi forradalom leverése után ismét Németországba költözött. ${ }^{46}$

Chownitz első alkalommal magyar darabok bemutatásáról referált a pesti Nemzeti Színházból, és megemlítette Bajza és Vörösmarty nevét. ${ }^{47}$

Chownitz két részes írást közölt Alexander Schmid(t) (? - ?), a pesti Német Színház igazgatójának Die Verstoßenen címü darabjáról, és kis mutatványt is közölt a második felvonás szövegéből. ${ }^{48}$

Pestről jelentkezett a Leuname nevü/álnevü levelező, aki Liszt fővárosi koncertjéről is beszámolt. ${ }^{49}$ Iglóból bizonyos Fr. Waniczek tudósított, akit nem tudtam azonosítani. Zeneegyleti hírek mellett Franz Preiß/Preyß (Igló,1797 - Igló, 1842) történeti és arcképfestőnél tett látogatásáról számolt be. ${ }^{50}$

Más magyar városok mellett Pécsett is volt a lapnak tudósítója, aki a színházi előadások címeit és a fellépő színészek neveit felsorolta. ${ }^{51}$ A ma már zömében azonosíthatatlan levelezők főleg helyi eseményekről számoltak be.

Egy ideig még neves magyar munkatársa is volt az Ost und Westnek a fiatal Szarvady Frigyes (1843-ig Hirschl, Újvidék, 1822 - Paris, 1882) személyében. Szarvady jogot tanult Pesten, Prágában és Bécsben, majd Pozsonyban telepedett le 1847-ben ügyvédként. A következő időszakban a párizsi Le Constitutionnel címü lap levelezője volt, majd 1848 után a magyar kormány megbízásából Pest és

${ }^{45}$ Chownitz, J. F., Tagesnovelletten aus Pesth $=$ OUW, Nr. 59, 25. Juni 1838, 243; Nr. 40, 18. Mai 1839, 164; Nr. 45, 5. Juni 1839, 186; Nr. 60, 27. Juli 1839, 251-252; Nr. 88, 2. November 1839, 382-383; Nr. 94, 23. November 1839, 412.

46 Chownitzhoz lásd még: Lengyel Márta, S., Egy fejezet 1848-i sajtónk történetéböl, Julian Chownitz „Die Opposition”-ja = OSZK Évkönyv 1978, Bp., 1980, 471-491.

${ }^{47}$ Chownitz, Mittheilungen aus Pesth $=$ OUW, Nr. 75, 19. September 1838, 309.

${ }^{48}$ Chownitz, J. F., Correspondenz aus Pesth, = OUW, Nr. 92, 17. November 1838, 377; Nr. 93, 21. November 1838, 382. A darab címe helyesen: Der Verstoßene, Bemutatója 1838. október 22én volt. Lásd ehhez: Deutsche Theater in Pest und Ofen 1770-1850, Normativer Titelkatalog und Dokumentation. Hrsg. v. Hedvig Belitska-Scholtz Scholtz und Olga Somorjai, Bp., Argumentum, [1995], Bd II 6519.

${ }^{49}$ Leuname, Pesther Zustände $=$ OUW, Nr. 10, 1. Februar 1840, 43.

${ }^{50}$ WaniczeK, Fr., Brief aus Iglau $=O U W$, Nr. 51, 25. Juni 1841, 207.

${ }^{51}$ Shandor, L., Aus Fünfkirchen, = OUW, Nr. 5, Februar 1841, 44. 
Párizs, illetve Pest és Bécs között közvetített diplomáciai ügyekben, és igyekezett a külföldet megnyerni a magyar szabadságharc ügyének. Ezt követően a Kölnische Zeitung párizsi levelezője lett, és tartott fenn innen kapcsolatot a magyar emigránsokkal. A frankfurti parlamentnek is tagja volt, majd 1850 után Angliában és Franciaorszában élt, csak az 1867-es amnesztia után tért vissza a Monarchiába, és lett a bécsi Neue Freie Presse tárcarovatának szerkesztője. ${ }^{52}$

Szarvady rendkívül pozitív kritikát jelentetett meg az Ost und Westben Julius Mosen (tkp. Julius Moses, 1803-1867) 1842-ben megjelent Kaiser Otto der Dritte címü drámájáról. Egyébként - túlzóan - korának egyik legjobb drámájának nevezte, dicsérte a konzekvens, zseniális jellemeket, a gondolatgazdag ábrázolást, egy világtörténelmi gondolat bemutatását, a kellően lekerekített jeleneteket, valamint a történeti hüséget. ${ }^{53}$

Szarvady recenziót közölt a „Deutsche Literatur” rovatban a prágai Libussa évkönyv 1842-es kötetéről is. A kötet munkatársai közül Uffo Horn, Moritz Hartmann, Friedrich Bach, Karl Egon Ebert, G. J. Kolar és Isidor Heller nevét emelte ki. ${ }^{54}$

Szintén ebben a rovatban írt Theodor Mügge (1802-1861) négy kötetes Toussaint címü regényéről. A zömmel kalandregényeket gyártó német író Stuttgartban 1840-ben megjelent regényének teljes címe „Toussaint oder der Negeraufstand in Haiti. Eine historische Erzählung für die Jugend" volt. Néhány epizódját Szarvady - valószínüleg joggal - fárasztónak tartja. ${ }^{55}$ Szarvady egyik utazásáról is beszámolt egy úti rajzában. ${ }^{56}$

Pestről tudósított a társas élet eseményeiről, koncertekről, lóversenyekről, színházi bemutatókról „Bhd.”. ${ }^{57}$ Egyik későbbi jelentkezéséből tudjuk meg teljes nevét: Bernhard Stolz, adatokat róla nem sikerült találnom. Több más téma mellett megemlíti a túlzott magyarkodást, melyet a haladás gátjának tart. ${ }^{58}$

Magyarországi úti élményeiről írt bizonyos Ignaz Grünberg, aki arra a megállapításra jut, hogy egy nemzet ,jellemét” a szórakozásaiban lehet a legjobban

52 Rózsa, Maria, Szarvady, Frigyes = Österreichisches Biographisches Lexikon, ab 1815 (2. überarbeitete Auflage.) Online-Edition Lfg. 3 (15.11.2014. http://www.biographien.ac.at/ oebl?frames=yes Utoljára megnyitva: 2017. 01. 26.)

53 Szarvady, Friedrich, Otto III., Tragödie von Julius Mosen (Aufgeführt auf der Prager Bühne am 27. April und 3. Mai.) $=$ OUW, Nr. 41, 21. Mai 1841, 166; Nr. 42, 25. Mai 1841, 171.

${ }^{54}$ SzArvady, Friedrich, Libussa. Jahrbuch für 1842: Herausgegeben von Paul Aloys Klar, k. k. Kreiskommissar, Direktor der Versorgungsanstalt für erwachsene Blinde etc. Prag $=O U W, \mathrm{Nr}$. 9, 1. Februar 1842, 35-36.

55 Szarvady, F., Toussaint. Roman von Theodor Mügge $=$ OUW, Nr. 52, 1. Juli 1842, 209.

${ }^{56}$ Fried. Sz-y, Badner Briefe $=$ OUW, Nr. 60, 28. Juli 1843, 241-242; Nr. 61, 1. August 1843, 244-245.

${ }^{57}$ Bhd., Aus Pesth, = OUW, Nr. 50, 24. Juni 1842, 201-202; Nr. 51, 28. Juni 1842, 205-206.

58 Stolz, Bernhard, Pesther Briefe $=$ OUW, Nr. 65, 16. August 1842, 261-262; Nr. 66, 19. August $1842,265$. 
megismerni. Személyes élményei alapján bemutatja a Komárom környéki falusi fiatalság táncait. ${ }^{59}$

Valószínủleg magyar tudósító volt Filó, aki Pestről tudósított, őt sajnos nem sikerült azonosítanom. ${ }^{60}$

Pozsonyból is tudósított valaki az időjárásról, színházi pletykákról a Franz Pokorny vezetése alatt álló Német Színházból. ${ }^{61}$ Franz/František Pokorny (Lstiboř, Tsch., 1797 - Wien, 1850) ${ }^{62}$ 1822-ben klarinétos volt a pozsonyi Városi Színházban, majd 1827-től a színház zenekarának vezetője, 1829-ben Pozsony tornamestere, 1835-ben átvette az eladósodott Városi Színház vezetését és nagy sikerekhez juttatta, különösen az opera terén. Ugyanez az L. K. írt az országgyúlés előkészületeiről a városban, valamint felhívta az olvasók figyelmét az „elmés” Adolf Neustadtnak a Pannoniában, a Preßburger Zeitung melléklapjában megjelent cikkére. ${ }^{63}$

A „Historische Denkwürdigkeiten” címü rovatban emlékezett meg Fr. F. monogramú szerző Szigetvár 1566-os elestéről, Zrínyi és a várvédők hősies haláláról. ${ }^{64}$

1848-ban még egy cseh szerzőtől, Viktor Bednáŕtól (?-?) származó kalandos, romantikus novellát találunk, középpontjában magyar hőssel, az osztrák örökösödési háború idejéből, nem várt fordulatokkal és csodás gyógyulással. ${ }^{65}$

Az 1848-as európai forradalmi hullám elérte a Cseh Királyságot és a vele egyesített Morvai Örgrófságot is, a lakosság a németekkel egyenlő jogokat követelt magának, persze természetesen a Habsburg Birodalmon belül. A „mesés eseményekről" Glaser először március 18-án írt, és üdvözölte a Monarchia népeinek adományozott alkotmányt, és felsorolta a prágai forradalmi eseményeket. ${ }^{66}$ A pesti történésekről, a 12 pont közzétételéről, Táncsics kiszabadításáról, a Nemzetőrség megalakításáról a Pester Zeitung alapján számolt be a lap. ${ }^{67}$ Glaser a kritikus időben vezércikkeit mindig Zeitbetrachtungen cím alatt tette közzé. Április 1-jén óvott attól, hogy az új alkotmányt a régi cseh rendi alapokra helyezzék. ${ }^{68}$ Felemelte szavát azért, hogy az új, a polgárságot képviselő népképviseletet csak a nép által válaszott képviselők alkothassák. ${ }^{69}$ Glaser szociális érzékenységét mu-

${ }^{59}$ GrÜNBERG, Ignaz, Bilder aus Ungarn $=$ OUW, Nr. 66, 19. August 1842, 265; Nr. 68, 26. August 1842, 273-274; Nr. 69, 30. August 1842, 277.

${ }^{60}$ Filó, Altes und Heuriges aus Pesth und Ofen $=O U W$, Nr. 87, 1. November 1842, 349-350.

${ }^{61}$ Pokornyhoz lásd: H. ReITterer, Franz Pokorny = Österreichisches Biographisches Lexikon. http://www.biographien.ac.at/oebl?frames=yes (Utoljára megnyitva: 2017. 02. 17.)

${ }^{62}$ L. K., Aus Preßburg $=$ OUW, Nr. 14, 17. Februar 1843, S. 54-55.

${ }^{63}$ L. K., Aus Preßburg = OUW, Nr. 17, 28. Februar 1843, 67.

${ }^{64}$ Fr. F., Merkwürdige That einer Frau bei der Belagerung von Szigeth $=O U W$, Nr. 22, 21. Februar 1846, 87; Nr. 24, 26. Februar 1846, 95.

${ }^{65}$ Bednák, Viktor, Der Ungar. Novelle $=$ OUW, Nr. 25, 26. Februar 1848, 97-99; Nr. 26, 29. Februar 1848, 101-102; Nr. 27, 2. März 1848, 105-107; Nr. 28, 4. März 1848, 109-111.

${ }^{66}$ R. G., Prag 18. März = OUW, Nr. 34, 18. März 1848, 133.

${ }^{67}$ Aus Pesth. $=$ OUW, Nr. 36, 23. März 1848, 143-144.

${ }^{68}$ Homan 1957, i. m. 89.

${ }^{69}$ Glaser, Rudolf, Zeitbetrachtungen $=O U W$, Nr. 40, 1. April 1848, 157. 
tatja, hogy egyik írásában arra intette a prágaiakat, hogy a népek felkelésével nem csak a középosztály, a polgárság szabadul fel, hanem a társadalom alsóbb rétegei is. ${ }^{70} 1848$ tavaszán nem voltak cseh részről Magyarországgal rokonszenvező hangok, később, az októberi bécsi forradalom után azonban változott ez a helyzet. ${ }^{71}$ Glaser Magyarországról úgy vélekedett, hogy egyetlen ország sem fog akkora átalakulásokon keresztülmenni, mint Magyarország. Glasert egy kultúrpolitikai orgánum kiadójaként természetesen foglalkoztatta a sajtószabadság megvalósulásának kérdése, és minden olyan kényszerintézkedést elutasított, amelyek az írók jogait korlátozták. ${ }^{72}$

A prágai forradalom kitörése után 1848 júniusára összehívták Prágába az ausztroszláv mozgalom kongresszusát azzal a céllal, hogy a Habsburg Birodalmat föderatív álammá alakítsák. A kongresszust a prágai diákok és polgárok felkelése szakította félbe, küzdelmüket Windisch-Graetz néhány nap alatt vérbe fojtotta. Az Ost und West azonban ebben az időben már nem jelent meg. A bécsi hatóságok már jó ideje bizalmatlanul szemlélték szerkesztőjének nemzetközi kapcsolatait, és a rendőrség Sedlnitzky rendőrminiszter utasítására Glasert titokban megfigyelte. ${ }^{73} \mathrm{Ez}$, valamint a gazdasági nehézségek, melyek következtében Glaser gyakran nem tudott honoráriumot fizetni szerzőinek, valamint a cenzúrával való állandó küzdelmei járultak hozzá a lap megszünéséhez. ${ }^{74}$ Az Ost und West utolsó száma 1848. június 10-én jelent meg.

Az Ost und West 12 évfolyama a lap munkatársai és tudósítói közös alkotó munkájának eredménye. Rudolf Glaser érdeme szervezői, a német és a szláv kultúrát összekötő tevékenységében rejlik. ${ }^{75}$ A szerkesztő ezen irányvonala mellett a magyar tematika mégis mindvégig jelen volt a folyóiratban. Ki kell emelni a többnyelvü, multikulturális közegből származó Rumy Károly Györgyöt, aki a szláv nyelvek mellett a magyar nyelv és kultúra lelkes népszerüsítője volt az egész európai régió német nyelvü periodikumaiban. Mellette a lap levelező tudósítója volt a szintén a Felvidékről származó Julian Chownitz. 1841-42-ben Szarvady Frigyes recenzióit is közölte az Ost und West. Megemlítendö, hogy a pesti és a pozsonyi német nyelvü lapok munkatársai állandóan figyelemmel kisérték, szemlézték az Ost und Westet. A fentebb nevezetteken kívül volt még sok más, ma már nem azonosítható magyar levelezője is a lapnak, akik tudósítottak a ma-

70 Hofman 1957, i. m. 90.

71 Lásd ehhez: PRAŽÁK, Richard, Az 1848-49-es magyar forradalom és szabadságharc csehés morvaországi visszhangja = Publicationes Univestitatis Miskolciensis, Sectio Philosophica. Tom 9, fasc. 1(2004), 75-76.

72 Hofman 1957, i. m. 100.

73 Mestan, Antonin, Die Monatsschrift der Gesellschaft des Vaterländischen Museums in Böhmen und Ost und West = Zeitschriften und Zeitungen des XVIII. und XIX. Jahrhunderts in Mittel- und Osteuropa, Hrsg. v. István Fried, Hans Lemberg, Edith Rosenstrauch-Königsberg, Berlin, Verlag Ulrich Camen, 1986, 208.

74 Hofman 1957, i. m. 35.

75 Hofman 1957, i. m. 41. 
gyar irodalmi, kulturális és társadalmi aktualitásokról. Összefoglalólag elmondható, hogy Glasernek lapjával sikerült egy egész Közép-Európa-szerte elismert, és a haladó erőket, legalább virtuálisan összekötő orgánumot létrehoznia, ami a magyaroszági német lapoknak ilyen mértékben nem adatott meg.

\section{RÓZSA, MÁRIA \\ Ungarische Bezüge in der Prager Zeitschrift Ost und West 1837-1848}

Die deutschsprachige Kulturzeitschrift Ost und West. Blätter für Kunst, Literatur und geselliges Leben erschien in Prag vom 1. Juli 1837 bis zum 10. Juni 1848. Die vom Prager Bibliothekar, Rudolf Glaser gegründete und redigierte Zeitschrift bemühte sich um Vermittlung zwischen Ost und West und enthielt viele Beiträge zur Literatur und Kultur vor allem zur tschechischen (böhmischen), russischen und polnischen Kultur, aber auch zu anderen Kulturen und Ländern. Mit Novellen auf Fortsetzung, Dramen, Gedichten, Reiseskizzen, Länder- und Völkergemälden, vermischten Aufsätzen über Literatur, Musik, Theater und Kunst versuchte sie den Zielsetzungen einer auf Interesse des Bildungsbürgertums basierenden Zeitschrift nachzukommen. Die in ganz Europa verbreitete und gelesene Zeitschrift gehörte zum Typ des für den Vormärz charakteristischen deutschsprachigen literarischen Blattes. Die Beiträge in Ost und West kamen aus Österreich, Deutschland, Polen, aus den Balkanländern und Rußland. Neben den ständigen Korrespondenten haben deutsche bzw. österreichische Dichter und Schriftsteller mitgewirkt. Es kam zweimal zur Veröffentlichung von ungarischen belletristischen Werken, ein Gedicht von Pál Jámbor erschien in der Übersetzung von Gustav Ignaz Zerffi, eine Novelle von Károly Kisfaludy wurde in Fortsetzungen 1847 abgedruckt. Regelmäßig berichtete im Blatt Karl Georg Rumy, eifriger Korrespondent deutschsprachiger Blätter im mitteleuropäischen Raum. Der junge Friedrich Szarvady schrieb einige Rezensionen für Ost und West. Über lokale Angelegenheiten - meist Theateraufführungen - berichtete Julian Chownitz.

Keywords: History of civilisation, 19th Century, Hungary, German cultural periodical in Prague, Mediation between East and West 